\title{
Jurist-Diction
}

Volume 4 No. 2, Maret 2021

\section{Prinsip Per Se Illegal dan Rule of Reason Secara Alternatif dalam Penetapan Harga Industri Jasa Freight Container (Uang Tambang)}

\author{
Siti Mahmuda
}

\author{
Siti.mahmuda-2016@fh.unair.ac.id \\ Universitas Airlangga
}

\begin{abstract}
How to cite:
Siti Mahmuda 'Prinsip Per Se Illegal dan Rule of Reason Secara Alternatif dalam Penetapan Harga Industri Jasa Freight Container (Uang Tambang)' (2021) Vol. 4 No. 2 Jurist-Diction.
\end{abstract}

Histori artikel:

Submit 9 Januari 2021;

Diterima 18 Februari 2021;

Diterbitkan 1 Maret 2021.

DOI:

10.20473/jd.v4i2.25787

p-ISSN: $2721-8392$

e-ISSN: $2655-8297$

\section{Abstract}

In antitrust law there are two approaches namely the juridical approach and the economic approach. Juridical approach includes per se illegal principle, rule of reason principle, and per se illegal principle and rule of reason principle applied alternatively. The per se illegal principle and rule of reason principle applied alternatively is a principle in antitrust law that combines per se illegal principle and rule of reason principle. The objective of this research is to analyze, the legal certainty of per se illegal principle and rule of reason principle implementation based on Law Number 5 of 1999 concerning Anti Monopoly Practice and Unfair Business Competition and the implementation of per se illegal principle and rule of reason principle alternatively in a pricefixing case regarding freight container service industry (required freightrate). The method used in this research is normative legal research which use sastatute approach, conceptual approach and case approach. From the results of the research, it can be concluded that there is no legal certainty regarding the implementation of per se illegal and rule of reason principle in a case and also the case of price-fixing in the freight container service industry (required freightrate) isusing per se illegal and rule of reason principle which applied alternatively andconcurrently.

Keywords: Rule of Reason Principle; Per Se Illegal Principle; Price Fixing; Freight Container.

\section{Abstrak}

Dalam Hukum Persaingan Usaha dikenal dua pendekatan yaitu pendekatan yuridis dan pendekatan ekonomi. Pendekatan yuridis meliputi Prinsip per se illegal, prinsip rule of reason, dan Prinsip per se illegal dan rule of reason secara alternatif. Prinsip per se illegal dan rule of reason secara alternatif merupakan suatu prinsip dalam hukum persaingan usaha yang penerapannya menggabungkan prinsip per se illegal dan rule of reason. Penelitian ini meliputi kepastian hukum penerapan prinsip per se illegal dan rule of reason dalam Undang-Undang No. 5 Tahun 1999 dan penerapan prinsip per se illegal dan rule of reason secara alternatif dalam penetapan harga industri jasa freight container (uang tambang). Metode penelitian yang digunakan adalah yuridis normatif dengan menggunakan pendekatan perundang-undangan, pendekatan konseptual, dan pendekatan kasus. Dari hasil penelitian dapat disimpulkan, tidak terdapat kepastian hukum mengenai kapan digunakannya prinsip per se illegal dan rule of reason dalam suatu perkara. dan juga kasus penetapan harga industri jasa freight container (uang tambang) menggunakan prinsip per se illegal dan rule of reason secara alternatif yang diterapkan secara bersamaan.

Kata Kunci: Prinsip Rule of Reason; Prinsip Per Se Illegal; Penetapan Harga; Freight Container. 


\section{Pendahuluan}

Komisi Pengawas Persaingan usaha atau yang disingkat KPPU dalam melakukan suatu analisa terhadap perilaku pelaku usaha yang terindikasi melanggar Undang-Undang No. 5 Tahun 1999 tentang Larangan Persaingan Usaha Tidak Sehat dan Praktek Monopoli yang selanjutnya disebut dengan UU Antimonopoli menggunakan dua prinsip. Prinsip pertama adalah prinsip yuridis (hukum) dan prinsip yang kedua adalah prinsip ekonomi, prinsip per se illegal dan rule of reason merupakan dua prinsip dari prinsip yuridis (hukum). ${ }^{1}$

Prinsip per se illegal merupakan prinsip yang digunakan oleh lembaga otoritas persaingan usaha untuk menilai setiap perjanjian atau kegiatan usaha tertentu yang dilakukan oleh pelaku usaha merupakan tindakan yang illegal, dengan tanpa pembuktian lebih lanjut atas dampak yang ditimbulkan dari setiap perjanjian atau kegiatan usaha. Yahya Harahap menggunakan istilah "sejak semula tidak sah" untuk menggambarkan konsep per se illegal, sehingga suatu perbuatan tersebut merupakan perbuatan yang "melanggar hukum". ${ }^{2}$ Kissane \& Benerofe menyatakan suatu tindakan pelaku usaha dikatakan illegal secara per se apabila “....it falls into a class of acts that courts have determined are so obviously anticompetitive that little or no analysis of the particular facts of the case at hand necessary to rule the act illegal", ${ }^{3}$

Berdasarkan pendapat Kissane \& Benerofe diatas maka dapat dikatakan bahwa suatu tindakan pelaku usaha yang oleh pengadilan dianggap bersifat anti persaingan terhadap fakta-fakta di sekitar tindakan itu tidak lagi terlalu penting untuk dianalisis demi menentukan suatu tindakan tersebut melanggar hukum. ${ }^{4}$ Sehingga perilaku pelaku usaha yang ditetapkan oleh pengadilan sebagai bentuk dari per se illegal, maka akan dihukum tanpa perlu penyelidikan yang rumit.

\footnotetext{
1 L. Budi Kagramanto, Larangan Persekongkolan Tender (Perspektif Hukum Persaingan Usaha) (Srikandi 2008).[219].

2 M. Yahya Harahap, Beberapa Tinjauan tentang Permasalahan Hukum (II) (Citra Aditya Bakti 1997).[28].

3 Kissane Jonathan dan Benerofe Steven J, 1996. Antitrust And The Regulation Of Competition, Glossary.

4 Arie Siswanto, Hukum Persaingan Usaha (Ghalia Indonesia 2004).[65].
} 
Dalam hal ini suatu perilaku dapat dikatakan per se illegal manakala perilaku tersebut hampir selalu bersifat anti persaingan, dan hampir tidak pernah membawa manfaat sosial, pengenaan prinsip per se illegal ini terhadap perilaku pelaku usaha juga harus didasarkan oleh pengalaman yang memadai pengadilan dalam memutus perilaku tersebut. ${ }^{5}$ Contoh penggunaan prinsip per se illegal yaitu pada Pasal 5 tentang Penetapan Harga.

Prinsip rule of reason merupakan prinsip yang digunakan untuk menilai setiap perjanjian atau kegiatan usaha tertentu yang dilakukan oleh pelaku usaha dimana perilaku tersebut bersifat menghambat atau mendukung persaingan usaha. ${ }^{6}$ Prinsip rule of reason dikatakan bahwa:

"Rule of Reason is a legal approach by competition authorities or the courts where an attempt is made to evaluate the procompotitive features business practices againts its anticompetitive effects to decide wether or not the pactice should be prohibited".'

Prinsip rule of reason adalah suatu pendekatan yang dilakukan oleh otoritas persaingan atau pengadilan untuk menilai suatu tindakan pelaku usaha termasuk kedalam pro persaingan atau antipersaingan, sehingga dapat memutuskan tindakan tersebut harus dilarang atau tidak. Prinsip rule of reason memungkinkan pengadilan untuk melakukan interpretasi terhadap Undang-Undang. Dalam hal ini contohnya yaitu Mahkamah Agung Amerika Serikat yang menetapkan standar rule of reason, dimana pengadilan dapat mempertimbangkan faktor kompetitif dan menentukan layak atau tidaknya suatu tindakan tersebut dinyatakan sebagai hambatan perdagangan sehingga menimbulkan adanya persaingan usaha tidak sehat. Hambatan perdagangan yaitu suatu hambatan yang bersifat mencampuri, mempengaruhi atau bahkan menghambat proses persaingan usaha. ${ }^{8}$ Contoh penggunaan prinsip rule of reason yaitu pada Pasal 11 tentang Kartel, dan Pasal 17 tentang Praktek Monopoli.

\footnotetext{
5 Andi Fahmi Lubis et al., Hukum Persaingan Usaha Antara Teks \& Konteks (Komisi Pengawas Persaingan Usaha 2009).[61].

6 ibid.

7 R.S Khemani dan D.M Shapiro, 1993, Glossary of Industrial Organisation Economics and Competition Law, OECD.

8 Andi Fahmi Lubis et al., Op.Cit.[66].
} 
Selain prinsip per se illegal dan rule of reason UU Antimonopoli juga mengatur mengenai prinsip per se illegal dan rule of reason secara alternatif. Prinsip per se illegal dan rule of reason secara alternatif berlaku terhadap rumusan pasal yang menggunakan prinsip per se illegal yang dianalisa dengan prinsip rule of reason, rumusan pasal yang menggunakan prinsip rule of reason yang dianalisa dengan prinsip per se illegal, dan rumusan pasal yang dianalisa menggunakan prinsip per se illegal dan rule of reason secara bersamaan. Kewenangan KPPU dalam menerapkan prinsip per se illegal dan rule of reason secara alternatif sendiri diatur dalam Pasal 35 UU Antimonopoli.

Contoh penerapan prinsip per se illegal dan rule of reason secara alternatif dalam hukum persaingan usaha Indonesia adalah putusan KPPU dengan Nomor Perkara 08/KPPU-L/2018 tentang Dugaan Pelanggaran Pasal 5 Ayat (1) UU Antimonopoli tentang Larangan Praktek Monopoli dan Persaingan Usaha Tidak Sehat dalam Industri Jasa Freight Container (Uang Tambang) pada Rute Surabaya Menuju Ambon oleh perusahaan pelayaran. Kasus ini bermula dari adanya laporan yang diterima oleh KPPU tentang adanya dugaan perjanjian penetapan harga uang tambang yang dilakukan oleh 4 (empat) pelaku usaha pelayaran dengan rute Surabaya menuju Ambon sekitar bulan Agustus 2017.

Keempat pelaku usaha yang terdiri dari PT Meratus Line, PT Pelayaran Tempuran Emas, Tbk, PT Salam Pasific Indonesia Line, dan PT Tanto Intim Line yang masing-masing pelaku usaha diduga telah membuat surat kenaikan tarif freight container dengan tanggal efektivitas yang sama. Kenaikan tarif ini berkisar 100\% yang diduga mengakibatkan konsumen tidak memiliki pilihan lain dan mengakibatkan barang-barang yang masuk ke Kota Ambon menjadi lebih mahal. ${ }^{9}$

Pada tanggal 23 Mei 2019 bertempat di kantor KPPU kantor perwakilan daerah Surabaya ditetapkan bahwa keempat pelaku usaha yang terdiri dari PT Meratus Line, PT Pelayaran Tempuran Emas, Tbk, PT Salam Pasific Indonesia Line, dan PT Tanto

\footnotetext{
${ }^{9}$ Komisi Pengawas Persaingan Usaha, 'Kppu Awasi Industri Jasa Freight Container', Komisi Pengawas Persaingan Usaha (2018), <http:/www.kppu.go.id/Id/Blog/2018/12/KppuAwasi-Industri-Jasa-Freight-Container/>, Diakses 20 Agustus 2019
} 
Intim Line dinyatakan telah terbukti secara sah dan meyakinkan melanggar Pasal 5 ayat (1) UU Antimonopoli. ${ }^{10}$ Pembuktian atau penilaian kasus diatas menggunakan prinsip per se illegal dan rule of reason secara alternatif dengan model penggunaan kedua prinsip tersebut secara bersamaan dimana rumusan pasalnya menggunakan prinsip per se illegal, namun dalam pembuktiannya investigator juga menggunakan prinsip rule of reason dalam penilaian terhadap kasus tersebut.

Maka berdasarkan uraian diatas perlu diteliti lebih jauh terkait Pengaturan Prinsip Per Se Illegal Dan Rule Of Reason Secara Alternatif Dalam Penetapan Harga Industri Jasa Freight Container (Uang Tambang).

\section{Metode Penelitian}

Penelitian ini merupakan penelitian yuridis normatif. ${ }^{11}$ Metode Pendekatan yang digunakan dalam penelitian ini adalah pendekatan perundang-undangan (statute approach), ${ }^{12}$ pendekatan konseptual (Conceptual Approach) ${ }^{13}$ dan Pendekatan Kasus (Case Approach $)^{14}$ untuk mengkaji permasalahan hukum yang ada. Sumber yang digunakan dalam penelitian ini berdasarkan kajian kepustakaan terhadap peraturan perundang-undangan, buku-buku, makalah, jurnal yang berkaitan dengan prinsip per se illegal dan rule of reason secara alternatif.

\section{Prinsip Per Se Illegal dan Prinsip Rule Of Reason}

Dalam UU Antimonopoli larangan yang bersifat per se illegal merupakan larangan yang tegas dalam rangka memberikan kepastian bagi para pelaku usaha

\footnotetext{
${ }^{10}$ Komisi Pengawas Persaingan Usaha, 'Kppu Putus Bersalah 4 Perusahaan Pelayaran, Total Denda Mencapai 20 Miliar Rupiah', Komisi Pengawas Persaingan Usaha (2019), <http://www. kppu.go.id/Id/Blog/2019/05/Kppu-Putus-Bersalah-4-Perusahaan-Pelayaran-Total-Denda-Mencapai-20-Miliar-Rupiah/>, Diakses 20 Agustus 2019.

${ }_{11}$ Depri Liber Sonata, 'Metode Penelitian Hukum Normative Dan Empiris : Karakteristik Khas Dari Metode Meneliti Hukum', (2014) Volume 8 Nomer 1 Fiat Justicia Jurnal Ilmu Hukum. [25-26].

${ }_{12}$ Peter Mahmud Marzuki, Penelitian Hukum E.d Rev (Prenada Media 2009).[133].

13 ibid.[177].

14 Soerjono Soekanto, Pengantar Penelitian Hukum (UI Press 1981).[10].
} 
terkait norma-norma larangan yang ada dalam persaingan usaha. ${ }^{15}$ Dalam UU antimonopoli prinsip per se illegal dapat dilihat dari ketentuan-ketentuan pasalpasalnya, yakni pencantuman istilah "dilarang”, tanpa anak kalimat “...yang dapat mengakibatkan...". ${ }^{16}$ Pasal-pasal dimaksud antara lain Pasal 5 Ayat (1), Pasal 6 tentang perlakuan diskriminasi, Pasal 7 tentang penetapan harga, Pasal 10 mengenai pemboikotan, Pasal 15 tentang perjanjian tertutup, Pasal 24 tentang hambatan produksi dan pemasaran, Pasal 25 tentang posisi dominan, Pasal 26 serta Pasal 27 tentang pemilikan saham. ${ }^{17}$

Pendekatan per se illegal oleh Mahkamah Agung Amerika Serikat pertama kali diterapkan dalam perkara United States v. Trans-Missouri Freight Association, yang diikuti kemudian dalam United States v. Joint Traffic Association. ${ }^{18}$ Pendekatan per se illegal ditinjau dari sudut proses administratif adalah mudah. Hal ini disebabkan karena metode ini membolehkan pengadilan untuk menolak melakukan penyelidikan secara rinci, yang biasanya memerlukan waktu lama dan biaya yang mahal guna mencari fakta di pasar yang bersangkutan. ${ }^{19}$ Oleh karena itu, dalam pendekatan per se illegal terdapat dua syarat dalam melakukan, yaitu: ${ }^{20}$

a. Harus ditujukan lebih kepada "perilaku bisnis" dari pada situasi pasar, karena keputusan dijatuhkan tanpa disertai pemeriksaan lebih lanjut, misalnya, mengenai akibat dan hal-hal yang melingkupinya. Metode pendekatan seperti ini dianggap fair, jika perbuatan illegal tersebut merupakan "tindakan sengaja” oleh perusahaan, yang seharusnya dapat dihindari.

b. Adanya identifikasi secara cepat atau mudah mengenai jenis praktik atau batasan perilaku yang terlarang. Dengan perkataan lain, penilaian atas tindakan dari pelaku usaha, baik di pasar maupun dalam proses pengadilan harus dapat diten-

\footnotetext{
${ }^{15}$ Mustafa Kamal Rokan, Hukum Persaingan Usaha (Teori dan Praktiknya di Indonesia) (Rajawali Press 2010).[60].

${ }^{16}$ Andi Fahmi Lubis et al, Op.Cit.[55].

${ }^{17}$ Ningrum Natasya Sirait et al., Ikhtisar Ketentuan Persaingan Usaha (The Indonesia Netherlands National Legal Reform Program (NLRP) 2010).[178-179].

${ }_{18}$ Andi Fahmi Lubis et al., Op.Cit.[56].

19 A.M Tri Anggraini. Larangan Praktek Monopoli dan Persaingan Tidak Sehat: Per Se Illegal atau Rule of Reason (FH UI 2003).[92].

${ }^{20}$ A.M Tri Anggraini, Op.Cit.[93]
} 
tukan dengan mudah. Meskipun demikian diakui, bahwa terdapat perilaku yang terletak dalam batas-batas yang tidak jelas antara perilaku terlarang dan perilaku yang sah.

Pendekatan rule of reason lahir dari tradisi common law pada tahun 1711 dalam perkara Mitchel $v$. Reynolds ${ }^{21}$, pengadilan memutuskan bahwa tidak semua perjanjian yang menghalangi perdagangan melanggar hukum, tetapi hanya perjanjian yang tidak masuk akal (unreasonable ones) yang dapat dikategorikan melanggar hukum. Perkara ini memberikan gambaran bagaimana suatu perjanjian yang bersifat antipersaingan dinyatakan tetap berlaku oleh hakim yang menangani perkara karena perjanjian tersebut dianggap layak meskipun bersifat antikompetitif karena menjauhkan masyarakat dari manfaat adanya persaingan.

Pendekatan rule of reason pertama kali dicetuskan oleh Justice White dalam memutus perkara Standart Oil Co. of N.J. v. United States sebagai suatu interprestasi pada periode awal diberlakukannya the Sherman Act Tahun 1911.22Penggunaan pendekatan rule of reason memungkinkan pengadilan untuk melakukan interpretasi terhadap UU. Mahkamah Agung Amerika Serikat, umpamanya telah menetapkan suatu standar rule of reason, yang memungkinkan pengadilan mempertimbangkan faktor-faktor kompetitif dan menetapkan layak atau tidaknya suatu hambatan perdagangan. Artinya untuk mengetahui apakah hambatan tersebut bersifat mencampuri, mempengaruhi, atau bahkan menghambat proses persaingan. ${ }^{23}$ Apabila terbukti secara signifikan adanya unsur yang menghambat persaingan, baru diambil tindakan hukum.

Dalam UU Antimonopoli prinsip rule of reason dapat dilihat dari ketentuanketentuan pasal-pasalnya, yakni pencantuman istilah "yang dapat mengakibatkan" atau "patut diduga". Kata-kata tersebut menyiratkan bahwa investigator perlu melakukan penelitian secara mendalam mengenai tindakan pelaku usaha, apakah

\footnotetext{
${ }^{21}$ Stephen F. Ross, Principles of Antitrust Law (The Foundation Press Inc. 1993).[14].

${ }^{22}$ Elyta Ras Ginting, Hukum Anti Monopoli Indonesia Analisis dan Perbandingan UU Nomor 5 Tahun 1999 (Citra Aditya Bakti 2001).[28].

${ }^{23}$ Thomas Sullivan and Jeffrey L., Understanding Anti Trust and Its Economics Implications (Matthew Bender and Co, 1994).[85].
} 
tindakan tersebut merupakan tindakan anti persaingan yang bersifat menghambat persaingan atau tidak. ${ }^{24}$

Prinsip Rule of Reason dalam UU Antimonopoli dapat ditemukan pada Pasal 4 tentang Oligopoli, Pasal 7 tentang Harga pemangsa atau jual rugi, Pasal 8 tentang Penetapan harga jual kembali, Pasal 9 tentang Pembagian wilayah, Pasal 11 tentang Kartel, Pasal 12 tentang Trust, Pasal 13 tentang Oligopsoni, Pasal 14 tentang Integrasi vertikal, Pasal 16 tentang Perjanjian dengan pihak luar negeri, Pasal 17 tentang Monopoli, Pasal 18 tentang Monopsoni, Pasal 19 tentang Pengusaan pasar, Pasal 20 tentang Kegiatan menjual rugi, Pasal 21 tentang Kecurangan dalam menetapkan biaya produksi, Pasal 22 tentang persekongkolan tender, Pasal 23 tentang Persekongkolan rahasia dagang, Pasal 26 tentang jabatan rangkap, Pasal 28 dan Pasal 29 tentang penggabungan, peleburan, dan pengambilalihan. Dalam penggunaan pendekatan rule of reason, UU Antimonopoli menetapkan adanya dampak atau akibat dari perjanjian atau kegiatan yang dilakukan pelaku usaha.

Alasan (reason) melarang suatu perjanjian atau kegiatan pelaku usaha berbeda-beda antara satu negara dengan negara lainnya tergantung dari tujuan hukum persaingan yang berlaku. Apabila tujuannya adalah tercapainya efisiensi (ekonomi) seperti di Amerika Serikat, maka praktik bisnisnya misalnya integrasi vertikal tidak akan dilarang apabila integrasi tersebut terbukti menghasilkan produk yang lebih efisien ketimbang tidak terintegrasi. ${ }^{25}$

Demikian juga apabila hukum persaingan yang berlaku di suatu Negara mempunyai tujuan non ekonomi, maka alasan non-ekonomi dapat digunakan dalam melarang suatu kegiatan usaha. Alasan non-ekonomi tentu saja berbedabeda antara satu Negara dengan Negara lain tergantung pada tujuan pembangunan ekonominya. ${ }^{26}$

${ }^{24}$ Andi Fahmi Lubis et al., Op.Cit.[55].

${ }^{25}$ Arini Pratiwi, 'Penerapan Pendekatan Per Se Illegal Dalam Putusan Komisi Pengawas Persaingan Usaha (Kppu) Terhadap Perkara Penetapan Harga Di Indonesia', Tesis (Program Studi Magister Kenotariatan Universitas Hasanuddin 2018).[77].

${ }^{26}$ ibid. 


\section{Kelebihan dan Kelemahan Prinsip Per Se Illegal dan Prinsip Rule Of Reason}

Prinsip Per Se Illegal dan Prinsip Rule of Reason dalam penerapannya di hukum persaingan usaha mempunyai kelebihan dan kekurangannya masingmasing. Kelebihan Penerapan Prinsip Per Se Illegal antara lain, ${ }^{27}$ pertama dalam Penerapan Prinsip Per Se Illegal terdapat kepastian hukum terhadap penyelesaian suatu persoalan hukum antipersaingan yang muncul. Kepastian hukum ini muncul karena suatu tindakan perilaku pelaku usaha baik melakukan perjanjian atau kegiatan dianggap selalu illegal atau antipersaingan dan selalu menimbulkan kerugian baik bagi konsumen maupun persaingan usaha itu sendiri. Dalam hal ini maka hakim dapat langsung memutus pelaku usaha melakukan tindakan antipersaingan tanpa membuktikan dampaknya terlebih dahulu. Contoh penerapannya yaitu apabila terjadi penetapan harga (price fixing), boycott, horizontal market division dan tying arrangement yang dilakukan pelaku usaha, maka hakim dapat menggunakan pendekatan ini secara langsung.

Kedua menghemat waktu dan biaya karena jika suatu perjanjian atau perbuatan yang dilakukan yang hampir pasti merusak dan merugikan persaingan, maka untuk apa lagi bersusah payah melakukan pembuktian terutama pada pembuktian dampak karena tidak hanya memakan waktu tetapi juga biaya mahal. Dalam hal ini penerapan Prinsip Per Se Illegal dalam pembuktian kasus akan mempersingkat waktu dan biaya, sehingga nantinya hakim dapat segera memutus dan menghentikan tindakan yang dilakukan pelaku usaha tersebut dan menghentikan kerugian yang ditimbulkan dari tindakan tersebut.

Ketiga penerapan prinsip per se illegal lebih memudahkan hakim memutuskan perkara persaingan usaha. Karena dalam hal ini, hukum persaingan telah memutuskan mengenai tindakan pelaku usaha tersebut dikategorikan illegal atau tidak, sehingga nantinya apabila terbukti tindakan pelaku usaha merupakan tindakan yang illegal maka hakim dapat memutus tindakan tersebut sebagai tindakan anti persaingan.

${ }^{27}$ Mustafa Kamal Rokan, Op.Cit.[62]. 
Salah satu manfaat besar dari penggunaan metode per se illegal adalah kemudahan dan kejelasannya dalam proses administratif. Di samping itu, pendekatan ini memiliki kekuatan mengikat yang lebih luas daripada laranganlarangan yang tergantung pada evaluasi mengenai pengaruh kondisi pasar yang kompleks. Oleh karena itu, penggunaan pendekatan ini dapat memperpendek proses pada tingkatan tertentu dalam pelaksanaan suatu UU. Suatu proses dianggap relatif mudah dan sederhana, karena hanya meliputi identifikasi perilaku yang tidak sah dan pembuktian atas perbuatan illegal tersebut. Dalam hal ini tidak diperlukan lagi penyelidikan terhadap situasi serta karakteristik pasar. ${ }^{28}$ Suatu perilaku yang ditetapkan oleh pengadilan sebagai per se illegal, akan dihukum tanpa proses penyelidikan yang rumit.

Selain memiliki kelebihan prinsip per se illegal juga memiliki kelemahan. Kelemahannya yaitu menerapkan prinsip per se illegal ini secara berlebihan dapat menjangkau perbuatan yang mungkin tidak merugikan atau bahkan mendorong persaingan menjadi salah secara hukum. Karena terkadang prinsip ini tidak selalu akurat menghasilkan pandangan apakah suatu tindakan pelaku usaha benar-benar tidak efisien dan merugikan konsumen. Tentunya hal ini akan menyebabkan penerapan hukum persaingan usaha menjadi kontraproduktif.

Prinsip rule of reason juga memiliki kelebihan dan kekurangannya. Kelebihannya yaitu, pertama Penggunaan pendekatan rule of reason memungkinkan pengadilan untuk melakukan interpretasi terhadap UU. Dalam hal ini, Mahkamah Agung Amerika Serikat, umpamanya, telah menetapkan suatu standar rule of reason, yang memungkinkan pengadilan mempertimbangkan faktor-faktor kompetitif dan menetapkan layak atau tidaknya suatu hambatan perdagangan. Artinya untuk mengetahui apakah hambatan tersebut bersifat mencampuri, mempengaruhi, atau bahkan menghambat proses persaingan. ${ }^{29}$ Apabila terbukti secara signifikan adanya unsur yang menghambat persaingan, baru diambil tindakan hukum.

\footnotetext{
${ }^{28}$ Andi Fahmi Lubis et al., Op.Cit.[60].

29 Thomas Sullivan and Jeffrey L, Op.Cit.[85].
} 
Kedua keunggulan sekaligus ciri pembeda pendekatan rule of reason adalah menggunakan analisis ekonomi untuk mencapai efisiensi guna mengetahui dengan pasti, yaitu apakah suatu tindakan pelaku usaha memiliki implikasi kepada persaingan yang berpotensi bagi terjadinya praktik monopoli dan atau praktik persaingan usaha yang tidak sehat. Dalam hal ini analisis ekonomi menggunakan beberapa istilah ekonomi seperti pasar bersangkutan (relevan market), kekuatan pasar (market power), hambatan terhadap pasar (barrier to entry), dan strategi harga (pricing strategic). ${ }^{30}$

The rule of reason merupakan "standar" yang membolehkan pengadilan untuk menilai ketidakjelasan atau tingkatan-tingkatan dari pengaruh persaingan. Dalam menerapkan suatu standard of reason untuk menilai suatu kesepakatan terlarang yang dinyatakan sebagai hambatan dalam perdagangan, dapat dikaji antara lain melalui tujuan dari kesepakatan tersebut, karakter (misalnya kekuatan) dari para pihak, dan akibat penting yang ditimbulkan dari perbuatan tersebut. ${ }^{31}$ Meskipun pada akhirnya Mahkamah Agung Amerika menggunakan pendekatan rule of reason yang fleksibel, yang menentukan bahwa suatu UU hanya menghukum perilaku yang unrasionable, namun belum terdapat standar yang jelas untuk menilai hal ini. ${ }^{32}$ Penerapan rule of reason merupakan pilihan yang tepat dalam melakukan penyelidikan. Analisis diperlukan untuk menentukan praktik tertentu yang menghambat atau mendorong persaingan, atau apabila terdapat tendensi keduanya, maka pengadilan akan mengambil langkah-langkah yang pengaruhnya paling menguntungkan (efisien) bagi masyarakat secara luas. ${ }^{33}$

Selanjutnya, selain keunggulan sebagaimana disebutkan di atas, Prinsip rule of reason juga mengandung suatu kelemahan yaitu, pertama bahwa prinsip ini membutuhkan waktu yang panjang dalam rangka membuktikan perjanjian, kegiatan,

\footnotetext{
${ }^{30}$ L.Budi Kagramanto, Mengenal Hukum Persaingan Usaha (Laros, 2008). [121].

${ }^{31}$ Ernest Gellhorn dan William E.Kovacic, Antitrust Law and Economics in a Nutshell (West Publishing 1994).[169].

32 A.M Tri Anggraini, Op.Cit.[105].

33 Arini Pratiwi, Op.Cit.[88-89].
} 
dan posisi yang tidak sehat dan menghambat persaingan usaha. ${ }^{34}$ Pembuktian menjadi panjang manakala hakim harus membuktikan adanya dampak yang ditimbulkan terlebih dahulu, baik dampak yang ditimbulkan bagi konsumen maupun bagi persaingan usaha itu sendiri dan apakah perbuatan tersebut menimbulkan adanya hambatan persaingan. Kedua prinsip ini menjadikan kepastian hukum lama didapatkan. Lebih dari itu, terkadang prinsip ini tidak sama hasil penelitiannya untuk suatu tindakan yang sama disebabkan tidak samanya dampak yang timbul dari tindakan pelaku usaha tersebut. ${ }^{35}$ Sehingga dalam hal ini hakim akan lebih sulit menentukan suatu tindakan pelaku usaha dikategorikan menghambat persaingan usaha atau tidak. Ketiga bahwa rule of reason yang digunakan oleh para hakim dan juri dalam sistem hukum Common Law mensyaratkan pengetahuan tentang teori ekonomi dan sejumlah data ekonomi yang kompleks, di mana mereka belum tentu memiliki kemampuan yang cukup untuk memahaminya, guna dapat menghasilkan keputusan yang rasional. Terbatasnya kemampuan dan pengalaman hakim untuk mengatasi proses litigasi yang kompleks, seringkali menimbulkan masalah sepanjang sejarah sistem pengadilan Amerika Serikat. ${ }^{36}$ Keempat yaitu tidak mudahnya untuk membuktikan para tergugat dalam hal ini pelaku usaha mengingat penggugat atau komisi yang bertugas mengawasi persaingan usaha harus menyediakan saksi ahli di bidang ekonomi, dan bukti dokumenter yang ekstensif dari para pesaing lainnya. Padahal biasanya pihak penggugat hanya memiliki kemungkinan yang kecil untuk memenangkan perkara, sehingga seringkali prinsip rule of reason dipandang sebagai a rule of per se legality. ${ }^{37}$ Kelima pengujian terhadap "dampak ekonomi" diakui oleh sementara kalangan merupakan salah satu kesulitan dari pembuktian dengan menggunakan pendekatan rule of reason. ${ }^{38}$ Hal ini disebabkan karena hampir tidak mungkin untuk dapat

\footnotetext{
${ }^{34}$ Mustafa Kamal Rokan, Op. Cit.[72].

35 ibid.[71-72].

${ }^{36}$ Andi Fahmi Lubis et al., Op.Cit.[66].

37 A.M Tri Anggraini, 'Persaingan Usaha dan Persekongkolan Tender', (2005) Volume 24 Nomor 2 Jurnal Hukum Bisnis.[9].

${ }^{38}$ Mustafa kamal Rokan, Op. Cit.[67].
} 
menetapkan tingkat persaingan terlebih dahulu secara terpisah dari produk dan harga. Apalagi, terdapat suatu kenyataan, bahwa ada beberapa transaksi bisnis yang dievaluasi berdasarkan hukum antitrust sebelum secara nyata melakukan tindakan yang berdampak anti kompetitif. Dalam mengevaluasi mengenai luasnya "kerugian kompetitif", biasanya akan selalu ditentukan pangsa pasar (market share) pihak tergugat di pasar terkait (relevant market). Semakin tinggi pangsa pasar suatu perusahaan, ${ }^{39}$ maka semakin besar pula luasnya kerugian terhadap persaingan, ${ }^{40}$ karena pelaku usaha yang memiliki kekuatan pasar (market power) yang besar, akan dapat meningkatkan harga secara mudah dan memaksakan keuntungan monopoli, dengan biaya yang harus ditanggung oleh konsumen. Jika suatu perusahaan atau pelaku usaha memiliki pangsa pasar yang tinggi, dan jika kekuatan ini digunakan untuk menetapkan harga yang lebih mahal, maka pelaku usaha akan berhasil mencapainya, paling tidak sampai terdapat pelaku usaha baru yang memasuki pasar, yang mampu menjual harga di bawah harga (monopoli) tersebut. ${ }^{41}$

\section{Kepastian Hukum Penerapan Prinsip Per Se Illegal Dan Rule Of Reason Dalam Undang-Undang 5 Tahun 1999}

Prinsip per se illegal dan rule of reason merupakan prinsip yang memiliki perbedaan ekstrim dimana prinsip per se illegal merupakan prinsip yang mengedepankan unsur illegal sehingga pengadilan dalam hal ini KPPU tidak perlu membuktikan dampak yang ditimbulkan atas perilaku yang dilakukan oleh pelaku usaha karena perilaku tersebut secara nyata-nyata merupakan perilaku yang illegal, sedangkan prinsip rule of reason lebih mengedepankan mengenai pembuktian dampak karena perilaku yang dilakukan pelaku usaha belum tentu merupakan perbuatan yang illegal. Namun, walaupun memiliki perbedaan yang ekstrim kedua prinsip merupakan satu kesatuan yang tidak dapat dipisahkan.

\footnotetext{
${ }^{39}$ Andi Fahmi Lubis et al., Loc.Cit.

${ }^{40}$ ibid.

41 ibid.
} 
Edward Brunet berpendapat bahwa walaupun prinsip per se illegal dan rule of reason merupakan prinsip yang berlawanan dan digunakan untuk menganalisis perkara antitrust/anti persaingan, tetapi kedua prinsip merupakan satu kesatuan yang tidak terpisahkan. ${ }^{42}$ Artinya, pada suatu perkara dengan pola perilaku yang sama pengadilan dapat melandasi keputusan dengan meggunakan metode prinsip rule of reason, dan dalam kasus lainnya menggunakan metode prinsip per se illegal, ${ }^{43}$ bahkan secara bersamaan kedua prinsip digunakan bersamaan untuk menganalisis suatu perkara. Walaupun prinsip per se illegal dan rule of reason memiliki inti yang berbeda keduanya dapat diterapkan secara bersamaan, saling melengkapi, dan bukan merupakan tindakan yang inkonsisten. ${ }^{44}$

Mengingat tidak terdapat kejelasan atau kepastian hukum mengenai kapan digunakannya kedua prinsip tersebut dalam suatu perkara, karena tidak semua perilaku yang bersifat membatasi (restrictive conduct) secara inheren merupakan perilaku yang bersifat anti persaingan. Maka untuk menyelesaikan permasalahan tersebut, pengadilan menggunakan kewenangan untuk dapat memilih prinsip yang paling baik digunakan pada suatu kasus, dengan berdasar pertimbangan kasus demi kasus. ${ }^{45}$

Berdasarkan ketidakjelasan atau tidak adanya kepastian hukum dalam penerapan prinsip per se illegal dan rule of reason maka lahirlah suatu prinsip yang menjembatani kedua prinsip tersebut yaitu yang dinamakan prinsip per se illegal dan rule of reason secara alternatif. Dalam hukum persaingan usaha Indonesia prinsip ini dibuktikan dengan adanya Pasal 35 UU Antimonopoli, dimana dalam pasal ini menyatakan mengenai wewenang KPPU dalam menerapkan kedua prinsip dengan mendasari pada prinsip yang paling baik digunakan (best practice) dalam menilai suatu perkara, namun dengan tetap berpedoman pada tujuan pembentukan UU Antimonopoli yaitu efisiensi dan kesejahteraan konsumen. ${ }^{46}$

\footnotetext{
${ }^{42}$ L. Budi Kagramanto, 'Persekongkolan Tender Dalam Perspektif Hukum Persaingan Usaha', Disertasi (Program Pascasarjana Universitas Airlangga 2007).[162].

${ }^{43}$ Andi Fahmi Lubis et al., Op.Cit.[81].

${ }^{44}$ L. Budi Kagramanto, Op.Cit.[162-163].

${ }^{45}$ Andi Fahmi Lubis et al., Loc.Cit.

46 ibid.
} 
Selain mengenai prinsip yang dijadikan sebagai metode untuk menganalisis suatu perkara, pengadilan dalam hal ini KPPU juga perlu memperhatikan mengenai ketentuan pengecualian yang diatur dalam UU Antimonopoli yaitu yang terdapat dalam Pasal 50 UU Antimonopoli. Pasal 50 UU Antimonopoli menyatakan bahwa: Yang dikecualikan dari ketentuan undang-undang ini adalah:

a. perbuatan dan atau perjanjian yang bertujuan melaksanakan peraturan perundangundangan yang berlaku; atau

b. perjanjian yang berkaitan dengan hak atas kekayaan intelektual seperti lisensi, paten, merek dagang, hak cipta, desain produk industri, rangkaian elektronik terpadu, dan rahasia dagang, serta perjanjian yang berkaitan dengan waralaba; atau

c. perjanjian penetapan standar teknis produk barang dan atau jasa yang tidak mengekang dan atau menghalangi persaingan; atau

d. perjanjian dalam rangka keagenan yang isinya tidak memuat ketentuan untuk memasok kembali barang dan atau jasa dengan harga yang lebih rendah daripada harga yang telah diperjanjikan; atau

e. perjanjian kerjasama penelitian untuk peningkatan atau perbaikan standar hidup masyarakat luas; atau

f. perjanjian internasional yang telah diratifikasi oleh Pemerintah Republik Indonesia; atau

g. perjanjian dan atau perbuatan yang bertujuan untuk ekspor yang tidak mengganggu kebutuhan dan atau pasokan pasar dalam negeri; atau

h. pelaku usaha yang tergolong dalam usaha kecil; atau

i. kegiatan usaha koperasi yang secara khusus bertujuan untuk melayani anggotanya.

\section{Penerapan Prinsip Per Se Illegal Dan Rule Of Reason Secara Alternatif Dalam}

\section{Penetapan Harga Industri Jasa Freight Container (Uang Tambang).}

Jasa pelayaran merupakan salah satu jasa pengangkutan yang cukup dibutuhkan oleh masyarakat terutama bagi masyarakat yang akan melakukan atau membutuhkan jasa pengangkutan ke luar pulau atau ke luar negeri. Jasa pelayaran dapat digunakan untuk mengangkut orang maupun barang. Dalam jasa pengangkutan di laut terdapat beberapa perusahaan yang menguasai pasar seperti PT Meratus Line, PT Pelayaran Tempuran Emas, Tbk, PT Salam Pasific Indonesia Line, dan PT Tanto Intim Line.

Menurut Tri Achmadi selaku Ahli Teknologi Kelautan Institut Teknologi Sepuluh November (ITS) Surabaya, Freight Container merupakan uang tambang 
atau biaya pengangkutan yang ditanggung oleh Ekspedisi Muatan Kapal Laut (EMKL) selaku konsumen terkait 4 komponen biaya, yaitu biaya kapital, biaya operasi, biaya perawatan dan perbaikan, serta biaya perjalanan. Biaya bongkar muat tidak termasuk kedalam freight container melainkan masuk kedalam biaya kepelabuhan. ${ }^{47}$ Pada tahun 2018 terdapat laporan yang diterima oleh KPPU mengenai dugaan perjanjian penetapan harga yang dilakukan oleh keempat perusahaan pelayaran tersebut yang berkaitan dengan penetapan harga dalam jasa freight container.

Gambaran umum mengenai permasalahan ini yaitu pada Rapat Tim Pengendalian Inflasi (TPID) di Provinsi Maluku, laporan yang disampaikan oleh Bank Indonesia menyatakan bahwa daerah yang menyumbang inflasi terbanyak di Indonesia pada bulan November adalah Provinsi Maluku khususnya pada Kota Ambon dari sektor logistik. Barang-barang yang terdapat di Kota Ambon, baik sembako maupun barang kebutuhan lainnya didatangkan dari Kota Surabaya menggunakan kontainer kapal laut. PT Meratus Line, PT Pelayaran Tempuran Emas, Tbk, PT Salam Pasific Indonesia Line, dan PT Tanto Intim Line adalah perusahaan pelayaran yang melayani pengiriman kontainer dengan rute Surabaya-Ambon dengan PT Salam Pasific Indonesia Line (SPIL) yang baru melayani rute SurabayaAmbon pada bulan Juli $2017 .{ }^{48}$ Dugaan mengenai kartel harga yang dilakukan oleh keempat perusahaan pelayaran ini terjadi sejak tahun 2017 hingga tahun 2018.

Pada tanggal 23 Mei 2019 bertempat di kantor KPPU kantor perwakilan daerah (KPD) Surabaya dibacakan putusan yang menetapkan bahwa keempat pelaku usaha yang terdiri dari PT Meratus Line, PT Pelayaran Tempuran Emas, Tbk, PT Salam Pasific Indonesia Line, dan PT Tanto Intim Line dinyatakan telah terbukti secara sah dan meyakinkan melanggar Pasal 5 ayat (1) UU Antimonopoli. ${ }^{49}$

\footnotetext{
${ }^{47}$ Putusan KPPU No. 08/KPPU-L/2018 tentang Kartel Harga Freight Container.[150].

${ }^{48}$ ibid.[3-4]

${ }^{49}$ Ismasi, 'Empat Perusahaan Pelayaran Terbukti Lakukan Monopoli Jasa Kontainer', Nusantara Maritime News (online) (2019), <https://maritimenews.id/empat-perusahaan-pelayaranterbukti-lakukan-monopoli-jasa-kontainer/>, Diakses 11 November 2019.
} 


\section{Penerapan Prinsip Per Se Illegal Dalam Penetapan Harga Industri Jasa Freight Container (Uang Tambang)}

Dalam kasus penetapan harga yang dilakukan oleh keempat perusahaan pelayaran yaitu PT Meratus Line, PT Pelayaran Tempuran Emas, Tbk, PT Salam Pasific Indonesia Line, dan PT Tanto Intim Line ditetapkan bahwa keempat perusahaan pelayaran tersebut terbukti secara sah dan meyakinkan melanggar Pasal 5 Ayat (1) UU Antimonopoli.

Pasal 5 Ayat (1) UU Antimonopoli berisi mengenai larangan bagi pelaku usaha untuk melakukan perjanjian penetapan harga dengan pelaku usaha pesaing. Pasal 5 ayat (1) berbunyi : "Pelaku usaha dilarang membuat perjanjian dengan pelaku usaha pesaingnya untuk menetapkan harga atas suatu barang dan atau jasa yang harus dibayar oleh konsumen atau pelanggan pada pasar bersangkutan yang sama."

Pasal 5 ayat (1) merupakan salah satu pasal yang menggunakan prinsip per se illegal, hal ini dapat dibuktikan dengan kata “...Dilarang...” dan tanpa menggunakan kata “...dapat mengakibatkan...”. Sehingga apabila menurut prinsip per se illegal maka penetapan harga dalam pembuktiannya tidak perlu membuktikan adanya dampak yang ditimbulkan dari adanya perilaku yang dilakukan pelaku usaha, karena perilaku tersebut merupakan tindakan yang illegal, sehingga pengadilan dalam hal ini KPPU hanya perlu membuktikan unsure unsur Pasal 5 ayat (1) UU Antimonopoli. Berdasarkan pedoman Pasal 5 unsur unsur dari Pasal 5 Ayat (1) UU Antimonopoli meliputi pelaku usaha, perjanjian, pelaku usaha pesaing, harga pasar, barang, jasa, konsumen, pasar bersangkutan, usaha patungan.

\section{Penerapan Prinsip Rule of Reason Dalam Penetapan Harga Industri Jasa Freight Container (Uang Tambang)}

Prinsip rule of reason merupakan prinsip yang menekankan mengenai pembuktian dampak. Apabila dikaitkan dengan Perkara No. 08/KPPU-L/2018 mengenai kasus dugaan penetapan harga yang dilakukan oleh 4 (empat) perusahaan pelayaran yaitu PT Meratus Line, PT Pelayaran Tempuran Emas, Tbk, PT Salam Pasific Indonesia Line, dan PT Tanto Intim Line. maka dalam putusannya terdapat 
penerapan prinsip rule of reason. Hal ini dapat dibuktikan dengan adanya pembuktian dampak yang dilakukan oleh KPPU. Dalam kaitannya dengan pembuktian dampak, dampak dibagi menjadi 2 (dua) yaitu dampak yang ditimbulkan atas perilaku pelaku usaha bagi konsumen dan dampak yang ditimbulkan atas perilaku pelaku usaha bagi pelaku usaha pesaing.

\section{Dampak yang Ditimbulkan Dari Adanya Penetapan Harga Industri Jasa Freight Container (Uang Tambang) Bagi Konsumen}

Dalam perkara No. 08/KPPU-L/2018 terdapat pembuktian dampak yang ditimbulkan atas perilaku pelaku usaha bagi konsumen Hal ini dibuktikan dengan kesaksisan yang diberikan konsumen dalam persidangan yang kemudian menjadi fakta persidangan dan mempengaruhi majelis komisi dalam menjatuhkan putusannya. Kesaksian yang diberikan konsumen atau dalam hal ini Ekspedisi Muatan Kapal Laut (EMKL) dalam persidangan yang berkaitan dengan dampak pada intinya berisi mengenai keberatan atas diberlakukannya surat penyesuain tarif dengan dalil harga yang diberikan terlalu tinggi dan kenaikan harga yang signifikan, sehingga atas tingginya harga tersebut mempengaruhi semakin tingginya harga jasa freight container yang ditawarkan oleh EMKL. Alasan jasa freight container melambung tinggi karena tidak adanya pilihan lain bagi EMKL untuk memilih perusahaan pelayaran dan harga yang diberikan perusahaan pelayaran masih menjadi pengaruh besar bagi EMKL untuk memberikan harga bagi jasa freight container yang ditawarkannya, hal ini dibuktikan dengan adanya tindakan EMKL yang mengeluarkan surat penyesuaian tarif rute Surabaya-Ambon kepada relasi/ pemilik barang sebagai dampak dari dikeluarkannya surat penyesuaian tarif dari 4 (empat) perusahaan pelayaran.

Dalam putusannya Majelis Komisi juga memperhatikan mengenai dampak yang ditimbulkan bagi masyarakat atas surat penyesuaian tarif yang dikeluarkan oleh 4 (empat) perusahaan pelayaran. Dalam pertimbangannya majelis menyatakan bahwa jenis muatan kontainer yang biasa dibawa ke Ambon dari Surabaya merupakan kebutuhan pokok dan bahan bangunan, sehingga dengan adanya 
kenaikan biaya sewa container rute Surabaya-Ambon tersebut berpotensi memicu kenaikan harga komoditas di Maluku, khususnya Kota Ambon. Ini karena, beberapa komoditas tersebut didatangkan dari luar Maluku, khususnya dari Jawa. Beberapa komoditas utama yang didatangkan dari luar Maluku merupakan komoditas bahan makanan. Kenaikan harga-harga akan berdampak pada menurunnya daya beli masyarakat. Dari data inflasi yang dimuat di laman BPS menyebutkan bahwa inflasi kota Ambon, secara year-on-year pada September 2017 mencapai 3,07\%. Inflasi tersebut utamanya disebabkan oleh kelompok bahan makanan yang mencatatkan inflasi sebesar 9,13\%. Selain itu, kesamaan besaran tarif freight container yang dikeluarkan oleh masing-masing Terlapor justru menyulitkan perusahaan EMKL dan/atau konsumen untuk berpindah ke perusahaan pelayaran lain yang kemudian mengakibatkan pilihan EMKL dan/atau konsumen menjadi terbatas.

Atas kesaksian dan pertimbangan tersebut Majelis Komisi berpendapat bahwa perusahaan pelayaran mempunyai kekuatan untuk menentukan harga yang ditunjukkan dengan harga jasa freight container yang masih sangat dipengaruhi oleh harga yang diberikan perusahaan pelayaran yang dibuktikan dengan tindakan konsumen/EMKL yang tidak akan mengeluarkan surat penyesuaian tarif rute Surabaya-Ambon kepada relasi/pemilik barang jika tidak ada surat penyesuaian tarif dari 4 (empat) perusahaan pelayaran.

\section{Dampak yang Ditimbulkan Dari Adanya Penetapan Harga Industri Jasa Freight Container (Uang Tambang) Bagi Pelaku Usaha Pesaing}

Dalam kasus penetapan harga industri jasa freight container (uang tambang) terdapat dampak yang ditimbulkan bagi pelaku usaha lain yang berada dalam pasar bersangkutan yang sama. Pertama dalam jasa pelayaran dengan rute SurabayaAmbon menggunakan struktur pasar oligopoli yaitu dimana hanya ada beberapa perusahaan saja yang menguasai suatu pasar. Dalam hal ini PT Tanto Intim Line, PT Pelayaran Tempuran Emas Tbk, PT Meratus Line, dan PT Salam Pasific Indonesia Lines merupakan perusahaan yang terdapat dalam jasa pelayaran dengan rute Surabaya-Ambon. Struktur pasar oligopoli merupakan suatu bentuk struktur pasar 
yang tidak sempurna sehingga dalam hal ini oligopoli dapat berpotensi menimbulkan persaingan usaha tidak sehat.

Dengan adanya bentuk struktur tersebut dapat menyebabkan adanya barrier to entry bagi pelaku usaha lain yang ingin masuk ke dalam pasar. Barrier to entry ini sendiri dapat terjadi karena pasar hanya dikuasai oleh beberapa perusahaan saja, sehingga apabila dikemudian hari terjadi perjanjian antar pelaku usaha pada pasar bersangkutan tersebut akan menyebabkan sulitnya pelaku usaha baru untuk masuk ke dalam pasar.

Kedua dalam hal market power, market power atau dalam bahasa Indonesia sering diterjemahkan menjadi kekuatan pasar, merupakan sebuah kekuatan bagi perusahaan untuk memperoleh laba sebesar-besarnya ${ }^{50}$. Perusahaan pelayaran yang telah lama masuk kedalam pasar bersangkutan akan memiliki market power yang besar dan memilki pangsa pasar yang lebih luas. Dengan adanya perjanjian penetapan harga freight container hal tersebut akan menimbulkan posisi dominan pada pasar bersangkutan tersebut, sehingga akan rentan terjadi penyalahgunaan posisi dominan yang ditujukan untuk menghambat pasar atau menghambat pelaku usaha lain diluar perjanjian tersebut. Pelaku usaha lain yang tidak terlibat dalam perjanjian tidak akan memiliki keistimewaan-keistimewaan atas diberlakunya perjanjian tersebut, selain itu juga dapat menimbulkan terjadinya diskriminasi bagi pelaku usaha pesaing yang menyebabkan mau tidak mau pelaku usaha tersebut harus keluar dalam pasar

Ketiga mengenai strategi konsumen akan lebih percaya dengan perusahaan yang sudah ada terlebih dahulu dibandingkan dengan pelaku usaha yang baru masuk pasar bersangkutan. Ketika sebuah perusahaan meluncurkan produknya dan produk tersebut memiliki kekuatan pasar, maka konsumen akan bersedia merogoh kocek lebih dalam untuk mendapatkan produk tersebut meskipun harganya naik. Atau dengan kata lain, perusahaan akan dapat menaikkan harga jual produknya tanpa

\footnotetext{
${ }^{50}$ Ahmad Kaylani, Negara dan Pasar Dalam Bingkai Kebijakan Persaingan (Komisi Pengawas Persaingan Usaha 2011).[40]
} 
harus takut kehilangan konsumennya. ${ }^{51}$ Sehingga apabila pelaku usaha tersebut tidak masuk kedalam perjanjian penetapan harga tersebut dan bahkan memberikan harga dibawah harga yang ditawarkan oleh 4 (empat) perusahaan pelayaran yang lain, maka akan menimbulkan sentimen bagi perusahaan pelayaran lain dan dapat menyebabkan terbentuknya perjanjian-perjanjian lain dengan tujuan untuk menyingkirkan pelaku usaha tersebut dari pasar bersangkutan. Namun, apabila pelaku usaha tersebut masuk kedalam perjanjian dan mengikuti harga pelaku usaha lain maka daya tawar kepada konsumen akan kalah dengan pelaku usaha yang telah ada sebelumnya.

Apabila dikaitkan dengan kasus diatas maka terdapat 3 (tiga) dampak yang ditimbulkan dari perjanjian penetapan harga yang dilakukan oleh 4 (empat) perusahaan pelayaran pada rute Surabaya-Ambon yaitu pertama menyebabkan terbentuknya barrier to entry bagi pelaku usaha baru yang akan masuk pada pasar bersangkutan tersebut. Kedua akan menimbulkan posisi dominan dari dibentuknya perjanjian penetapan harga dimana akan rentan sekali terjadi penyalahgunaan posisi dominan yang ditujukan untuk menghambat pasar atau menghambat pelaku usaha lain diluar perjanjian. Ketiga dalam hal strategi pemasaran konsumen akan lebih percaya dengan pelaku usaha yang sudah ada sebelumnya, sehingga bagi pelaku usaha baru yang menurunkan harga dibawah harga yang ditawarkan pelaku usaha lain akan menimbulkan sentimen yang dapat menyebabkan terbentuknya perjanjian lain dengan tujuan menyingkirkan pelaku usaha tersebut dari pasar bersangkutan.

\section{Analisis Pengenaan Prinsip Per Se Illegal dan Rule of Reason Secara Alternatif Dalam Penetapan Harga Industri Jasa Freight Container (Uang Tambang)}

Prinsip per se illegal dan rule of reason secara alternatif merupakan gabungan dari prinsip per se illegal dan rule of reason. Prinsip per se illegal dan rule of reason secara alternatif berlaku terhadap rumusan pasal yang menggunakan prinsip per se illegal yang dianalisa dengan prinsip rule of reason, rumusan pasal yang menggunakan prinsip rule of reason yang dianalisa dengan prinsip per se illegal, 
dan rumusan pasal yang dianalisa menggunakan prinsip per se illegal dan rule of reason secara bersamaan. Apabila dikaitkan dengan kasus diatas maka KPPU menggunakan konsep prinsip per se illegal dan rule of reason secara alternatif yang diterapkan secara bersamaan dalam suatu kasus. Hal ini dibuktikan dengan rumusan pasal 5 ayat (1) UU Antimonopoli yang menggunakan prinsip per se illegal, namun dalam putusannya Majelis Komisi juga memperhatikan mengenai dampak yang ditimbulkan atas penetapan harga yang dilakukan oleh perusahaan pelayaran bagi konsumen.

Penerapan prinsip per se illegal dan rule of reason secara alternatif tidak diatur secara khusus dalam UU Antimonopoli, namun dalam Pasal 35 mengenai tugas KPPU pada ayat (1) dan (2) dinyatakan bahwa KPPU bertugas untuk menilai perjanjian dan kegiatan yang dilakukan oleh pelaku usaha baik yang dilakukan sendiri maupun yang dilakukan bersama-sama. Jika dikaitkan dengan Pasal 35 UU Antimonopoli, maka Pasal 35 tidak menjelaskan secara eksplisit mengenai penerapan prinsip per se illegal dan rule of reason secara alternatif, namun dijelaskan secara implisit.

Makna dari Pasal 35 terutama pada ayat (1) dan (2) bermakna sangat luas, sehingga tidak ada kejelasan mengenai spesifikasi apa saja yang dapat diterapkan atau dapat dilakukan dalam melakukan penilaian tersebut.. Namun, kembali lagi apabila dilihat secara luas mengenai makna dari Pasal 35 terutama pada Ayat (1) dan Ayat (2) UU Antimonopoli yang menyatakan bahwa KPPU bertugas untuk menilai suatu perjanjian atau kegiatan yang dilakukan oleh pelaku usaha yang diduga melanggar praktik monopoli dan persaingan usaha tidak sehat, maka KPPU berwenang dalam menerapkan semua prinsip dan semua bentuk bukti, dll yang dianggap membantu KPPU dalam menyelesaikan suatu perkara.

Selain Pasal 35 UU Antimonopoli tidak ada aturan lain yang membahas mengenai kewenangan KPPU dalam menerapkan suatu prinsip dalam menganalisa suatu perjanjian atau kegiatan , bahkan dalam RUU tentang larangan praktik monopoli dan persaingan usaha tidak sehat pun tidak membahas mengenai penerapan prinsip, yang baru hanya membahas mengenai penerapan indirect evidence dalam suatu perkara. 


\section{Kesimpulan}

Dalam penerapan prinsip per se illegal dan rule of reason tidak terdapat kejelasan atau kepastian hukum mengenai kapan digunakannya kedua prinsip tersebut dalam suatu perkara. Maka untuk menyelesaikan permasalahan tersebut, pengadilan menggunakan kewenangan untuk dapat memilih prinsip yang paling baik digunakan. Selain itu, dalam menerapkan suatu prinsip KPPU dapat berpedoman kepada karakteristik dari prinsip dan pengecualian yang diatur dalam Pasal 50 UU Antimonopoli.

Dalam Putusan KPPU No. 08/KPPU-L/2018, KPPU menggunakan konsep prinsip per se illegal dan rule of reason secara alternatif yang diterapkan secara bersamaan. Hal ini dibuktikan dengan rumusan pasal 5 ayat (1) UU Antimonopoli yang menggunakan konsep prinsip per se illegal, namun dalam putusannya Majelis Komisi juga memperhatikan mengenai dampak yang ditimbulkan, pembuktian dampak merupakan konsep yang dianut dalam pembuktian prinsip rule of reason. Kewenangan KPPU dalam menerapkan prinsip per se illegal dan rule of reason secara alternatif diatur dalam Pasal 35 Ayat (1) dan (2), namun makna kewenangan tersebut bersifat implisit bukan eksplisit. Maka apabila dikaitkan dengan kasus diatas KPPU berwenang dalam menerapkan prinsip per se illegal dan rule of reason secara alternatif. .

\section{Daftar Bacaan}

\section{Buku}

Ahmad Kaylani, Negara dan Pasar Dalam Bingkai Kebijakan Persaingan (Komisi Pengawas Persaingan Usaha 2011).

A.M Tri Anggraini. Larangan Praktek Monopoli dan Persaingan Tidak Sehat: Per Se Illegal atau Rule of Reason (FH UI 2003).

Andi Fahmi Lubis et al., Hukum Persaingan Usaha Antara Teks \& Konteks (Komisi Pengawas Persaingan Usaha 2009).

Arie Siswanto, Hukum Persaingan Usaha (Ghalia Indonesia 2004).

Elyta Ras Ginting, Hukum Anti Monopoli Indonesia Analisis dan Perbandingan 
UU Nomor 5 Tahun 1999 (Citra Aditya Bakti 2001).

Ernest Gellhorn dan William E.Kovacic, Antitrust Law and Economics in a Nutshell (West Publishing 1994).

Kissane Jonathan dan Benerofe Steven J,. Antitrust And The Regulation Of Competition (Glossary 1996).

L. Budi Kagramanto, Larangan Persekongkolan Tender (Perspektif Hukum Persaingan Usaha) (Srikandi 2008). , Mengenal Hukum Persaingan Usaha (Laros, 2008).

Mustafa Kamal Rokan, Hukum Persaingan Usaha (Teori dan Praktiknya di Indonesia) (Rajawali Press 2010).

M. Yahya Harahap, Beberapa Tinjauan tentang Permasalahan Hukum (II) (Citra Aditya Bakti 1997).

Ningrum Natasya Sirait et al., Ikhtisar Ketentuan Persaingan Usaha (The Indonesia Netherlands National Legal Reform Program (NLRP) 2010).

Peter Mahmud Marzuki, Penelitian Hukum E.d Rev (Prenada Media 2009).

R.S Khemani dan D.M Shapiro, Glossary of Industrial Organisation Economics and Competition Law (OECD 1993)

Soerjono Soekanto, Pengantar Penelitian Hukum (UI Press 1981).

Stephen F. Ross, Principles of Antitrust Law (The Foundation Press Inc.1993).

Thomas Sullivan and Jeffrey L., Understanding Anti Trust and Its Economics Implications (Matthew Bender and Co, 1994).

\section{Jurnal}

A.M Tri Anggraini, 'Persaingan Usaha dan Persekongkolan Tender', (2005) Volume 24 Nomor 2 Jurnal Hukum Bisnis.

Depri Liber Sonata, 'Metode Penelitian Hukum Normative Dan Empiris: Karakteristik Khas Dari Metode Meneliti Hukum’, (2014) Volume 8 Nomer 1 Fiat Justicia Jurnal Ilmu Hukum. 


\section{Skripsi/ Tesis/ Disertasi}

Arini Pratiwi, 'Penerapan Pendekatan Per Se Illegal Dalam Putusan Komisi Pengawas Persaingan Usaha (Kppu) Terhadap Perkara Penetapan Harga Di Indonesia', Tesis (Program Studi Magister Kenotariatan Universitas Hasanuddin 2018).

L. Budi Kagramanto, 'Persekongkolan Tender Dalam PerspektifHukum Persaingan Usaha', Disertasi (Program Pascasarjana Universitas Airlangga 2007).

\section{Laman}

Ismasi, 'Empat Perusahaan Pelayaran Terbukti Lakukan Monopoli Jasa Kontainer', Nusantara Maritime News (online) (2019), <https://maritimenews.id/empatperusahaan-pelayaran-terbukti-lakukan-monopoli-jasa-kontainer/>, Diakses 11 November 2019.

Komisi Pengawas Persaingan Usaha, 'Kppu Awasi Industri Jasa Freight Container', Komisi Pengawas Persaingan Usaha (2018), <http://www.kppu.go.id/Id/ Blog/2018/12/Kppu-Awasi-Industri-Jasa-Freight-Container/>, Diakses 20 Agustus 2019.

Komisi Pengawas Persaingan Usaha, 'Kppu Putus Bersalah 4 Perusahaan Pelayaran, Total Denda Mencapai 20 Miliar Rupiah', Komisi Pengawas Persaingan Usaha (2019), <http://www.kppu.go.id/Id/Blog/2019/05/KppuPutus-Bersalah-4-Perusahaan-Pelayaran-Total-Denda-Mencapai-20-MiliarRupiah/>, Diakses 20 Agustus 2019.

\section{Perundang-undangan}

Undang-Undang Nomor 5 Tahun 1999 Tentang Larangan Praktek Monopoli Dan Persaingan Usaha Tidak Sehat, (Lembaran Negara Republik Indonesia Tahun 1999 Nomor 33).

Peraturan Komisi Pengawas Persaingan Usaha Nomor 4 Tahun 2011 Tentang Pedoman Pasal 5 (Penetapan Harga).

Peraturan Komisi Pengawas Persaingan Usaha No. 3 Tahun 2009 tentang Pedoman Penerapan Pasal 1 Angka 10 tentang Pasar Bersangkutan.

Peraturan Komisi Pengawas Persaingan Usaha No. 1 Tahun 2019 tentang Tata Cara Penanganan Perkara Praktik Monopoli dan Persaingan Usaha Tidak Sehat.

Putusan KPPU No. 08/KPPU-L/2018 tentang Kartel Harga Freight Container. 
Siti Mahmuda: Prinsip Per Se Illegal...

--halaman ini sengaja dibiarkan kosong-- 